\title{
The quarry proposed by St Marys Cement Inc. for a location near Carlisle, Ontario should not be permitted: Proponents' Brief
}

\author{
Michelle Conklin, Jake L'Ecuyer, Nicole Morgan, Natalie Proracki, \\ Tom Schiks, Brad Summerfield, Seth Wasylycia \\ This study was conducted under the supervision of Professor Glenn Fox, \\ Food, Agricultural and Resource Economics, Ontario Agricultural College \\ University of Guelph, Guelph, Ontario, Canada
}

\begin{abstract}
This paper presents a set of arguments claiming that construction of the quarry near Flamborough, Ontario proposed St. Mary's Cement Inc. should not be permitted. First, the quarry would violate local citizens' property rights, compromise community health and safety, and incur excessive economic costs. Precautionary measures are insufficient, such that the quarry is expected to irreparably damage drinking water and quality of life. Second, the area proposed for aggregate extraction is mostly undeveloped, containing unique, valuable natural features and ecological linkages. Despite regulation and monitoring according to the provincial Aggregate Resources Act, rehabilitation of the site after aggregate extraction would be inadequate in returning the land to its former condition. This will result in habitat fragmentation and loss of high quality farmland. Furthermore, the construction of the quarry is not permitted under current City of Hamilton zoning regulations; the City of Hamilton, along with the city's Public Health Services, filed an official objection against construction. Finally, a GIS study has selected a more suitable alternative site for aggregate extraction near Carlisle, which meets the geographic, topographic, and mineral needs of St. Mary's Cement Group without disturbing habitat or nearby communities.
\end{abstract}

$\mathrm{I}^{\mathrm{n}}$ 2006, St Marys Cement Inc. began the search for a quarry site, and eventually came across the proposed location near Carlisle, Ontario. The intended name for this site is the St Marys Flamborough Quarry. This proposed quarry has come under an increasing amount of scrutiny. Despite zoning regulations specifying the area for agricultural use and nature conservancy, St Marys Cement Inc. has applied for an amendment to the by-law. The City of Hamilton states that the city and the City of Hamilton Public Health Services filed an objection to the quarry [1]. We object to the proposed quarry regarding legal considerations and property rights violations, social and economic impact, health and safety concerns, and environmental and rehabilitation concerns. For these reasons, we believe that the quarry should not be permitted. Furthermore, we provide suggestions for an alternative quarry site.

\section{Legal Considerations ANd Property Rights VIOLATIONS}

The currently proposed land use for the Flamborough site is determined by official plans and zoning by-laws. Zoning designates activities that are permissible on a property. As stated by Cornish, a Ministerial Zoning Order in April 2010 put a freeze on the allowable land use for the Flamborough site [2]. The Order stated that the area is to remain zoned for agriculture and conservation management. The Ontario Aggregate Resources Act and a report by Baker and Shoemaker state that since aggregate extraction is not permitted under either agriculture or conservation management zoning, this land use is deemed unacceptable [3] [4]. It is stated by the Ontario Ministry of Municipal Affairs and Housing that the proposed St Marys Flamborough Quarry site is situated within the Ontario Greenbelt, a protected green space comprising approximately 1.8 million acres of agricultural land and environmentally sensitive ecosystems [5]. According to the New Rural Hamilton Official Plan the property falls under the designation of the Greenbelt Natural Heritage system [1]. Hamilton's Official Plan also outlines that the site contains Significant Woodlands. Winfield explains that aggregate extraction poses a significant threat to natural heritage features, source water, and agricultural land [6]. Third parties have advocated that the use of aggregate pits is incongruous with the goals of the Greenbelt Plan, and should not be permitted within the protected regions [6].

Noise created by aggregate operations (frequent blasting at the site and increased truck traffic) would constitute public nuisance. Brubaker claims that excessive noise interferes with public use and enjoyment of land [7]. The Ontario Ministry of Natural Resources states that there are many sensitive receptors, including residential use and camping facilities are present within the area [8]. Brubaker explains how dust and pollution would constitute trespass, such that the aggregate company places substances on private 
property belonging to others [7]. Environment Canada and Griffiths state that dust can impair air quality and agricultural productivity [9] [10]. Increased pollution from truck traffic would exacerbate air pollution further. Tietenberg suggests that these examples of air pollution are forms of externalities, where the cost of an action is incurred by a party who did not agree to the action [11].

\section{SOCIAL \& ECONOMIC IMPACTS}

There are various social and economic impacts from the construction of a quarry. An informational sheet provided by St Marys Cement Inc. under the section "What are the economic benefits to the community from this quarry?" claims that the project will generate more than $\$ 11$ million in economic benefits each year once the facility is operational [12]. Unfortunately only a fraction of this income would remain in the community. The two largest economic factors, employees and operating supplies (which constitute 76.3 percent of the benefits) are under the assumption that 100 percent of employees and supplies come from within the city of Hamilton. With 23.1 percent of the benefits paid to the province Ontario as income and sales taxes, and license fees, only 0.6 percent of the benefits will remain in the community [13].

A study performed by Erickcek examined the impact of distance from a gravel pit on property value. This study found that property within 0.5 kilometres of the mine dropped in value by 25 percent or more, within a 1 kilometre distance exhibited a 20 to 15 percent drop, and within 4 to 5 kilometres away exhibited a drop of 5 to 7 percent [14]. An article in the Hamilton Spectator states that the average price of non-condominium properties was \$268,729 [15]. This implies that the average home at a distance of 0.5 kilometre would face a $\$ 67,182.25$ decrease in the value of the property, while those located 4 to 5 kilometres away would face a $\$ 13,436.45$ loss in property value. Decreased home value would in turn discourage further housing development in the area. Even if the quarry is completely rehabilitated and housing value returns to its full potential, anyone selling during the rehabilitation period would still be at a loss and would not be compensated.

With the construction of the quarry there will also be added costs to the community. The Center for Spatial Economics claims there will be increased costs to the community through increased fire and emergency services [16]. There may also be costs added for upgrading area roads to accommodate increased traffic stemming from the quarry, as well as increased legal, consulting and staff costs as can be seen in other towns that have previously had quarry projects [16]. Examining these factors presents the sizeable potential economic costs to the Flamborough community created by the quarry.

\section{HeAlTh AND SAFETY}

The primary health concern associated with the proposed quarry at the Flamborough site is the reduction in quality and quantity of groundwater supplied to municipalities and communities in the vicinity. According to an Environmental Review Tribunal case in 2008, the proposed operations for the quarry at the Flamborough site include open excavation that will extend below the water table [17]. The Review Tribunal found that this could affect the quality of drinking water for residents living in the vicinity who are dependent on water from the aquifer; in particular, there are concerns for the community of Carlisle, which draws on a municipal well system relying on the aquifer [17]. According to a 2006 study presented to the City of Hamilton by SNC-Lavalin Inc., approximately 23000 residents within the rural areas of the City of Hamilton are dependent on groundwater supplies [18]. In the community of Carlisle alone, two thirds of households are dependent on groundwater supplies from the aquifer [18]. A review of several primary documents completed in 2009 by Kenneth Raven indicates that unmitigated development of the quarry (i.e. without an effective groundwater recirculation system) will have unacceptable impacts on local residential wells [19]. While St. Marys Cement Inc. proposed to implement such a system, there is a lack of demonstrable field evidence that the groundwater recirculation system can work; the effectiveness of the technology remains unproven at the Flamborough site [19]. Even if a groundwater recirculation system was implemented and found to be effective in the recirculation of groundwater back to municipal wells, there remains potential for technological or operational failure. Without a back-up system, groundwater supplies to municipalities in the vicinity of the quarry would continue to be at risk for reduced quantity and quality of groundwater supplies.

Additional social implications of the proposed quarry include safety concerns for those living and commuting in the vicinity of the quarry and along its proposed haul routes. According to a report by iTRANS Consulting Inc. for St. Marys Cement Inc. in 2009, the majority of the haul route (and possible alternatives) used for transporting materials and products run through residential, business, and agricultural areas [20]. The primary access route to the quarry site is located in a primarily rural residential area [20]. Increased traffic of heavy trucks in areas where people work and live increases the potential for automotive accidents and human harm.

\section{ENVIRONMENTAL CONCERNS}

The coalition Friends of Rural Communities and the Environment (FORCE) state that those living in the Carlisle community agree that the area proposed for aggregate development is "large, relatively undeveloped, and rich in natural features and linkages" [21]. Many assessments and reviews have been conducted to determine the impacts that the quarry will have on the environment. In 2009, the environmental studies specialist Brian Hindley discussed the effects on groundwater discharge in an Aquatic Environment Review of Aggregate Resources Act application [22]. He 


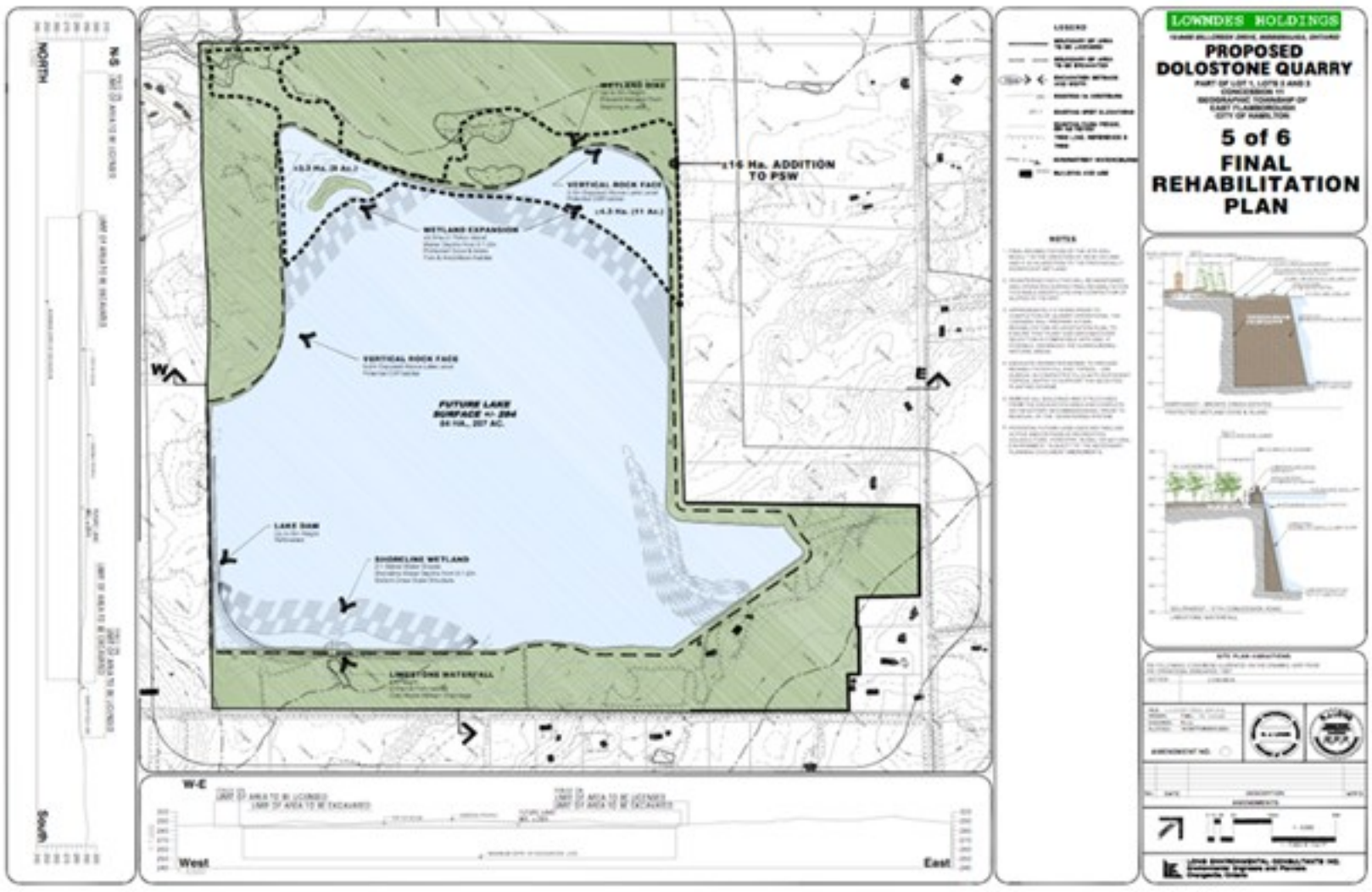

Figure 1 Long Environmental Consultants Inc. and Lowndes Holdings final rehabilitation plan for roposed St. Marys Cement Flamborough Quarry near Carlisle, Ontario. This figure illustrates proposed areas of removal. The rehabilitation plan outlines the area that will be converted to a new land use (lake). This is incongruent with the current land use zoning, and the Ministry of Natural Resources guidelines for rehabilitating aggregate sites [33]

examined the proposed site and found that Mountsberg Creek, a wetland in the area, supports cool and coldwater fish communities, and recommended that sources of groundwater discharge to these communities be protected [22]. Hindley states that the quarry will eliminate approximately 25 percent of surface drainage, which may result in loss of the fishery [22]. A study by Cowx concludes that a change in groundwater supply can result in a change in water temperature, which in turn can reduce aquatic species populations [23]. Furthermore, Hindley's examination of the site concluded that "this application as proposed will have significant, or at least unknown, environmental effects and should not proceed" [22].

A Natural Environment Report on the Flamborough Quarry Haul Route prepared by Savanta Inc. in 2008 discusses the potential direct impacts of the quarry's presence on the environment. These impacts include increases in sunscald, desiccation, wind throw, invasive species, light, noise, dust, and wildlife-related automotive collisions [24]. The report lists the multiple wetlands that would be negatively affected by aggregate development: Beverly Swamp, Puslinch Southeast Swamp, Fletcher Creek Swamp Forest, Guelph Junction Woods, Mountsberg East
Wetlands, and Carlisle North Forest [24]. The report also states that many of these wetlands are habitats for rare and at-risk species, including the ribbonsnake (Thamnophis sauritis) [24]. Furthermore, the report discusses the impacts of construction and increased transportation on the surrounding environment. There is likelihood of increased runoff effects, such as erosion and sediment loading, on receiving streams; this could lead to elimination of aquatic habitats [24]. A study by Trombulak et al suggests that runoff and dust from new road works would also have an effect on vegetation. When dust settles on vegetation, photosynthesis, respiration, and transpiration are blocked [25]. On a large scale, this causes physical harm to entire plant communities. Finally, the report suggests that heavier traffic leads to increased wildlife fatalities by vehiclewildlife collisions [25].

A preliminary report by North-South Environmental Inc. discusses environmental features of the Flamborough site and potential impacts associated with the proposed quarry. The report describes the site as an area rich in plant and animal species within a region of intense human development, where "biodiversity continues to be threatened as the total area of available habitat declines" [26]. The 
natural features and their diversity and connectivity in this area should be maintained along with their ecological function. The report concludes that a quarry operating below the groundwater table would have serious long- and shortterm environmental implications for the area's ecological features [26].

Evidence provided by experts and specialized organizations studying the environmental impacts of the quarry are clear that this project will cause excessive harm to the environment. The impacts of the disturbance on existing ecosystems are substantial and may cause instability and decrease overall biodiversity.

\section{REHABILITATION CONCERNS}

The Ministry of Natural Resources requires, under provincial legislation, that aggregate site rehabilitation give ample opportunity for firms to promote relations with site neighbours, environmentalists, and future prospective communities [3]. However, this opportunity is often wasted due to environmentally insensitive designs. In a rehabilitation plan drawing from 2008 for the proposed dolostone quarry near Carlisle, Ontario (fig. 1), St. Marys Cement Inc. includes the creation of a large lake surrounded by areas of wetland and forest.

The Ministry of Natural Resources states that quarry rehabilitation is intended to restore the site to its former use/condition, or to a condition that is compatible with local land use [26]. In 2005, North-South Environmental Inc. performed an assessment of the environmental features in the proposed site and reported that half of the property contains productive land, while the other half is comprised of "diverse natural vegetation cover" [27]. This confirms that the proposed rehabilitation plan will in no way restore the site to appropriate conditions as outlined by the Ministry; vast quantities of agricultural land will be lost, and the adjacent vegetation cover will not benefit from a large, artificial body of water. Although St. Marys Cement Inc. endorses the idea that aggregate extraction is an interim land use [28], FORCE indicates that the design for the rehabilitation project ensures that losses would be permanent and the site would forever be transformed into a foreign landscape [29]. By not returning the site to its former condition, St. Marys Cement Inc. will effectively remove agriculturally productive land, fragment the remaining habitat, and destroy valuable ecosystem services.

If St Marys Cement Inc. did improve their rehabilitation plan by incorporating the current land-use, it would not guarantee such a project would ever be completed. Cases exist where it is acknowledged that aggregate firms are doing a poor job of rehabilitating sites. In the annual report by the Environmental Commissioner of Ontario, it was stated that $83 \%$ of sites had compliance problems in rehabilitation [30]. Miller also notes that 6,500 quarries have been abandoned since 1990 with an average rehabilitation rate of 13 sites per year [30]. It may not be surprising that rehabilitation has not been effective; in 1997, according to a letter from the Mayor of Hamilton, the Ministry of Natural Resources transferred responsibility to the aggregate industry association, initiating a period of self-regulation [31]. The construction of the quarry and the proposed rehabilitation process will not satisfy requirements under Ministry legislation. It will also fail to convert the ecosystem back to a pristine condition with similar ecological characteristics and capabilities. The trend of poor rehabilitation practices in the industry put the local communities at risk of dealing with scarified landscapes for longer than promised.

\section{Potential Alternative Site}

Research performed by Summerfield et al. found that there are sites more suitable than the St Marys Flamborough Quarry site near Carlisle that might also meet the needs of the cement company [32]. A simple geographic information system (GIS) exercise using layers of Wellington county along with some field exploration revealed an excellent site adjacent to the 401 at County Road 34 in Wellington. The site has $6 \mathrm{~T}$ soil and is currently used as agricultural land. It is hilly and stony with only one residence in view. The 401 would muffle the sound and still allow quick and easy transportation to the GTA while the brush and marginal farmland would not be a significant environmental loss [32].

\section{CONCLUSION}

Due to the aforementioned concerns involving legal and property rights, social and economic issues, health and safety effects, environmental issues and problems involved with rehabilitation, the St Marys Flamborough Quarry should not be constructed.

\section{REFERENCES}

1. City of Hamilton- Planning \& Economic Development. (2010). City of Hamilton- New Rural Hamilton Official Plan. Retrieved from http://www.hamilton.ca/CityDepartments/PlanningEcDe v/Divisions/StrategicServicesSpecialProjects/Policy+Pla nning/HamiltonNewOfficialPlan/Rural-HamiltonOfficial-Plan.htm

2. Cornish, D. (2010). Quarry opponents advised to remain vigilant. Flamborough Review. Retrieved from http://www.flamboroughreview.com/news/article/29442 4

3. Ministry of Natural Resources. (1990). Aggregate Resources Act, R.S.O. 1990, Chapter A.8.

4. Baker, D. \& D. Shoemaker. (1995). Environmental Assessment and Aggregate Extraction in Southern Ontario: The Puslinch Case. Department of Environment and Resource Studies: University of Waterloo Case Report, 1-39.

5. Ontario Ministry of Municipal Affairs and Housing. (2005). Protecting the Greenbelt: Greenbelt Act, 2005. Retrieved from http://www.mah.gov.on.ca/Page195.aspx 
6. Winfield, M. (2005). Submission to the standing committee on general government regarding Bill 135, the Greenbelt Act. The Pembina Institute. Retrieved from

http://pubs.pembina.org/reports/Bill135CommitteeSubm issionJanuary27-2005.pdf

7. Brubaker, E. (1995). Property Rights in the Defence of Nature. Toronto: Earthscan Publications. Web.

8. Ministry of Natural Resources. (2006). 5.00.10 Hours of Operation, Blasting Restrictions and Response to Emergencies, Aggregate Resources and Policy Manual. Retrieved

from http://www.mnr.gov.on.ca/en/Business/Aggregates/2Col umnSubPage/266561.html\#5 0 Miscellaneous

9. Environment Canada. (2009). Pits and Quarries Guidance. National Pollutant Release Inventory. Retrieved from http://www.ec.gc.ca/inrpnpri/default.asp?lang=en\&n=A9C1EE34-1\#s8

10. Griffiths, H. (2003). Air Pollution on Agricultural Crops, Ontario Ministry of Agriculture, Food \& Rural Affairs. Retrieved from http://www.omafra.gov.on.ca/english/crops/facts/01015.htm\#particulate

11. Tietenberg, T. (2002). Environmental and Natural Resource Economics. Addison Wesley Publishing: Massachusetts.

12. St. Marys Cement Inc. (2010). Frequently Asked Questions. Retrieved from http:/www.stmaryscement.com/saintmaryscementinc/_ Uploads/CurrentInfo/FAQ.pdf

13. Chen, D. \& J.M. Mintz. (2003). Taxing investments: On the Right Track, But at a Snail's Pace. C.D. Howe Institute, $72 . \quad$ Retrieved from http://www.cdhowe.org/pdf/backgrounder_72.pdf

14. Erickcek, G. (2006). An Assessment of the Economic Impact of the Proposed Stoneco Gravel Mine Operation on Richland Township. W.E. Upjohn Institute for Employment Research.

15. Local resale prices up 6 percent. (2007, February 6). The Hamilton Spectator, pp. A12-13.

16. Center for Spatial Economics. (2009). The Potential Financial Impacts of the Proposed Rockfort Quarry. Retrieved from http://www.town.caledon.on.ca/contentc/townhall/depart ments/planningdevelopment/Schedule_B_to_CAO_Rep ort_2009-001.pdf

17. Environmental Review Tribunal of Ontario. (2008). Friends of Rural Communities and the Environment v. Director, Ministry of Environment, Case Number: 08-053. Retrieved from http://www.ert.gov.on.ca/files/DEC/08053d1.pdf

18. SNC-Lavalin Inc. (2006). Hamilton Groundwater Resources Characterization and Wellhead Protection Partnership Study. Retrieved from http:/hamilton.ca/NR/rdonlyres/FBBB1593-8291-48B38F57-
C5B360355B85/0/GroundwaterCharacterizationstudy.pd $\mathrm{f}$

19. Raven, K. (2009). Hydrogeological Review of Aggregate Resources Act Application, St. Marys Flamborough Quarry Site, City of Hamilton. INTERA Engineering Ltd. Retrieved from http://www.stopthequarry.ca/documents/FORCE\%20AR A\%20Objections\%20May\%202009\%20$\% 20$ Raven\%20Review.pdf

20. iTRANS Consulting Inc. (2009). Preliminary Draft Haul Route Evaluation Report. Retrieved from http://www.hamilton.ca/NR/rdonlyres/E267D03AF2E8-42B8-ACBD-

F1C00EB9CC83/0/APreliminaryDraftHaulRouteReport Part1.pdf

21. Friends of Rural Communities and the Environment. (2010). Environmental \& Natural Features. Retrieved from

http://www.stopthequarry.ca/TheCase/environmental.ph $\mathrm{p}$

22. Hindley, B. (2009). Letter from Aquafor Beech Ltd. To Friends of Rural Communities and the Environment, re: Aquatic Environment Review of Aggregate Resources Act Application, St. Marys Flamborough Quarry Site, City of Hamilton. Retrieved from http://www.stopthequarry.ca/documents/FORCE\%20AR A\%20Objections\%20May\%202009\%20-

$\% 20$ Hindley\%20Review.pdf

23. Cowx, I. (2000). Potential impact of groundwater augmentation of river flows on fisheries: a case study from the River Ouse, Yorkshire, UK. Fisheries Management and Ecology, 7, 85-96.

24. Savanta Inc. (2008). Flamborough Quarry Haul Route Study-Natural Environment Report. Retrieved from http://www.stopthequarry.ca/documents/SMC_PIC5\%20 Trans $\% 20$ Study $\% 20-\% 20$ Reports $\% 20$ -

$\% 20 \mathrm{C} \% 20 \% 20$ Natural $\% 20$ Environment $\% 20$ Report $\% 20$ (Savanta).pdf

25. Trombulak, S. \& C. Frissell. (2000). Review of Ecological Effects of Roads on Terrestrial and Aquatic Communities. Conservation Biology, 14: 18-30.

26. Ministry of Natural Resources. (2009). Rehabilitating Aggregate Sites. Retrieved from http://www.mnr.gov.on.ca/en/Business/Aggregates/2Col umnSubPage/STEL02_167060.html

27. North-South Environmental Inc. (2005). Preliminary Report of the Environmental Features and Potential Impacts associated with the Proposed Lowndes Quarry. Retrieved from http://www.stopthequarry.ca/documents/FORCE\%20Lo wndes\%20Ecology\%20Report\%20July\%202005a.pdf

28. St. Marys Cement Inc. (2008). Flamborough Quarry. Retrieved from http://www.flamboroughquarry.ca/process.php

29. Friends of Rural Communities and the Environment. (2007). In request of a review of the Aggregate 
Resources Act and Planning Act (File \#424711-6). Environmental Commissioner for Ontario

30. Miller, G. (2007). Annual Report 2006-2007: Reconciling Our Priorities, Environmental Commissioner of Ontario. Retrieved from http://www.eco.on.ca/eng/uploads/eng_pdfs/2007/Annua 1 report-0607-FINAL-EN.pdf

31. Eisenberger, F. (2008). Letter from Mayor of Hamilton to Minister of Natural Resources. Retrieved from http://www.margaretmccarthy.ca/Cansfield- $\quad 1 . p d f$
32. Summerfield, B., T. Schicks, J. Ippolito, N. Piattelli, \& C. Williamson. (2010). Prospective Aggregate Sites for Wellington County. NRS*3100-Resource Planning Techniques, University of Guelph.

33. Long Environmental Consultants Inc. (2004). Proposed Dolostone Quarry: Final Rehabilitation Plan (Drawing 5 of 6). Retrieved from http://www.hamilton.ca/CityDepartments/PlanningEcDe v/Divisions/Planning/Development/FlamboroughQuarry. htm 